\title{
REVIEW OF THE FOSSIL RECORD OF STURGEONS, FAMILY ACIPENSERIDAE (ACTINOPTERYGII: ACIPENSERIFORMES), FROM NORTH AMERICA
}

\author{
ERIC J. HILTON AND LANCE GRANDE \\ Department of Geology, Field Museum of Natural History, 1400 South Lake Shore Drive, Chicago, Illinois 60605, <ehilton@fieldmuseum.org>, \\ $<$ lgrande@ fieldmuseum.org >
}

\begin{abstract}
The pre-Pleistocene fossil record of sturgeons (family Acipenseridae) from North America is reviewed based on a survey of reports in the literature and firsthand examination of specimens in museum collections. We provide a redescription of the only known specimen of $†$ Protoscaphirhynchus squamosus (Late Cretaceous, Montana), a very poorly preserved specimen for which few morphological details can be determined. Three taxa described as species of the genus Acipenser from North America ( $\dagger$ A albertensis, $\dagger$ A. eruciferus, and $\dagger A$. ornatus) were described based on isolated and fragmentary remains, and are here considered to be nomina dubia. The earliest reported remains of North American sturgeons are from the Late Cretaceous (Santonian to Campanian Milk River Formation). There is a relatively continuous record, with the exception of the Eocene and Oligocene, in which there are few (potentially in the Eocene) or no (Oligocene) known specimens available in collections. We have found that nearly all specimens are best regarded as Acipenseridae indeterminate genus and species due to their fragmentary preservation and lack of preserved diagnostic characters.
\end{abstract}

\section{INTRODUCTION}

$\mathrm{T}$ HE FOSSIL record of Acipenseriformes (sturgeons, paddlefishes, and their close fossil relatives) has been the subject of a number of recent studies (e.g., Grande and Bemis, 1991, 1996; Jin, 1995, 1999; Jin et al., 1995; Grande et al., 2002; Hilton, 2004; Grande and Hilton, 2006). However, the fossil record of sturgeons (family Acipenseridae) is exceedingly poor and has not recently been reviewed in detail. Two problems exist that hinder the interpretation of the fossil record of sturgeons. The first of these difficulties lies in the conservative nature of the morphology of the members of Acipenseridae. The conservative morphology of sturgeons has, in part, led to difficulty in differentially diagnosing extant genera such as Acipenser Linnaeus, 1758 (Findeis, 1997); its impact on diagnosing fossil taxa is therefore compounded. Woodward (1889a: 28), for instance, in discussing specimens from the Eocene London Clay, wrote: "The form [of a fossilized scute of a sturgeon], so far as recognizable, also corresponds with that of one of the dorsal scutes of an existing Acipenser. It is quite impossible, however, to found upon a series of isolated fossils of this kind a scientifically-defined species." The second problem regarding the fossil record of sturgeons is the fragmentary nature of the fossils that do exist. The earliest known member of the sister group of Acipenseridae, the family Polyodontidae, is $\dagger$ Protopsephurus Lu, 1994 (see Grande et al., 2002) from the Early Cretaceous of China, suggesting the acipenserids were also around at least since the Early Cretaceous, although undisputed fossil sturgeons have not been found before the Late Cretaceous. The known fossil record of sturgeons consists of mostly isolated and fragmentary scutes, fin spines, fulcra, and broken dermal bones of the skull and pectoral girdle.

Many of the fossil taxa included in Acipenser are indistinguishable from living taxa (Woodward, 1889a, 1889b, 1895; Wilimovsky, 1956; Bemis et al., 1997; Choudhury and Dick, 1998). There is much misidentification of small, fragmentary fossils as sturgeon remains. Some of this misidentification may be forgiven, as many groups of fishes have ornamented dermal bones that can be remarkably similar to the ornamentation found in sturgeons, at least superficially (e.g., some ariid catfishes). As an extreme example, Woodward (1895) considered some specimens that had been identified as being from sturgeons to be remains of a chondrichthyan and an aulopiform teleost (see Grande and Hilton, 2006: table 1). Acipenserid fossils have been recorded throughout the Northern Hemisphere, including many fragmentary unnamed records (e.g., from the Miocene of Japan, Yabumoto et al., 1997), as well as several nominal forms that, based on the published figures and descriptions, are best regarded as Acipenseridae indeterminate genus and species (e.g., †"A." zhylgensis Nessov in Nessov and Kaznyshkin, 1983 and $†$ "A." chilini Nessov in Nessov and Kaznyshkin, 1983).

In this paper, we have three primary objectives. First, we provide a redescription of the single poorly preserved specimen of $\uparrow$ Protoscaphirhynchus Wilimovsky, 1956, based on new observations. Unfortunately, its preservation does not allow us to differentially diagnose this genus, although we are able to clarify and describe newly discovered features for this taxon. Second, we review the nominal fossil species of the genus Acipenser from North America. We then review the record of unnamed sturgeon material from North America based on review of the literature as well as survey of the collections of many museums and institutions. The emphasis of our review is of the pre-Pleistocene records of sturgeons. Many Pleistocene remains exist (e.g., from the Tulare Formation of California, including many fragmentary specimens in the collections at UCMP and a nearly complete parasphenoid at LACM). Holocene sturgeon remains are often associated with archeological sites (e.g., Swift and Wing, 1968; Follett, 1975; Gobalet, 1990), but will not be discussed further here. This paper is intended to complement our description of a new, well-preserved fossil sturgeon from the Late Cretaceous of Montana (Grande and Hilton, 2006) and our (Hilton, Grande, and Bemis) ongoing studies of the comparative osteology and phylogenetic systematics of fossil and living sturgeons.

\section{INSTITUTIONAL ABBREVIATIONS}

AMNH, American Museum of Natural History, New York; ANSP, Academy of Natural Sciences, Philadelphia; BMNH, The Natural History Museum, London; CMN, Canadian Museum of Nature, Ottawa; FMNH, Field Museum of Natural History, Chicago; LACM, Los Angeles County Museum, Los Angeles; MCZ, Museum of Comparative Zoology, Cambridge; MOR, Museum of the Rockies, Bozeman; NJSM, New Jersey State Museum, Trenton; PU, Princeton University (housed at Yale University); TMP, Royal Tyrrell Museum of Palaeontology; UAF, University of Alaska, Fairbanks; UALVP, University of Alberta Laboratory of Vertebrate Palaeontology, Alberta; UCMP, University of California Museum of Paleontology, Berkeley; UMMP, University of Michigan Museum of Paleontology, Ann Arbor; USNM United 
States National Museum, Washington DC; UW, University of Wyoming, Laramie.

\section{REDESCRIPTION OF †PROTOSCAPHIRHYNCHUS SQUAMOSUS WILIMOVSKY, 1956}

In this section, we provide a redescription of $\dagger$ Protoscaphirhynchus squamosus based on our observations of the singleknown specimen. As shown below, this specimen is poorly preserved. However, because some of our interpretations differ from the original description and for the sake of completeness in our review of the North American fossil record of Acipenseridae, we include this redescription.

\section{SYSTEMATIC PALEONTOLOGY}

Class Osteichthyes Huxley, 1880

Subclass ACTINOPTERYGII Cope, 1887 (sensu Rosen et al., 1981)

Infraclass ACTINOPTERI Cope, 1871 (s. Rosen et al., 1981)

Series Chondrostei Müller, 1844 (s. Grande and Bemis, 1996)

Order ACIPENSERIFORMES Berg, 1940 (s. Grande et al., 2002)

Family ACIPENSERIDAE Bonaparte, 1831 (s. Bemis et al., 1997)

Genus †PROTOSCAPHIRHYNCHUS Wilimovsky, 1956

$†$ PROTOSCAPHIRHYNCHUS SQUAMOSUS Wilimovsky, 1956 Figures 1, 2

Protoscaphirhynchus squamosus WiLIMOvsky, 1956, p. 1207, fig. 1, pl. 132, figs. 1-3. BRYANT, 1989, p. 18.

Diagnosis. - Due to the poor preservation of most of the only known specimen, we cannot provide a differential diagnosis for $\dagger P$. squamosus, the only nominal member of this genus. Wilimovsky's (1956) diagnosis for the genus and species cited the scalation covering the entire body and the relatively short length of the head as unique among acipenserids. We regard the specimen as insufficiently preserved to evaluate these characters critically (e.g., most of the body is not preserved), although we refrain from referring to it as a nomen dubium until characters at other levels of the family are better understood.

Description.-Because most of the skeleton is not preserved, few meristic and no morphometric data could be recorded; those that could are provided in the descriptive sections below. We estimate that the specimen was between 600 and $700 \mathrm{~mm}$ TL in life.

Very little of the skull of $\dagger$ Protoscaphirhynchus is preserved, and that which is, is crushed and very poorly preserved (Fig. 1.1). The surface of the skull roofing bones that are labeled as frontals, parietals, and the pterotic by Wilimovsky (1956: fig. 1) are ornamented (fr, pa, and dpt, respectively, in Fig. 1.1). We were unable, however, to confirm Wilimovsky's interpretation of the shape of these bones (his self-admitted "best guess" interpretation) because the sutures and details of the specimen are not preserved. Portions of the dorsal bones of the left side of the snout are preserved, but no details of this portion of the skull could be determined. The subopercle reported by Wilimovsky (1956: fig. $1 ;=$ opercle of Wilimovsky, 1956) is, in fact, the ventral surface of the left clavicle (see below; Fig. 1.2). Nothing is preserved of the jaws, hyoid arches, or branchial arches.

The only portion of the axial skeleton that is preserved is the exoskeleton of the caudal region (i.e., the vertebral column is completely missing). The caudal fin region is the best-preserved portion of $\dagger$ Protoscaphirhynchus (Fig. 2). The internal skeleton of the caudal fin is largely not visible, as it is covered by the exoskeleton; only portions of seven hypural elements are exposed (hyp, Fig. 2). Only the bases of a few of the ventralmost caudal fin rays are preserved (cfr, Fig. 2). The exposed lateral surface of the caudal fin is covered by four or five rows of rhomboid caudal scales that are positioned obliquely below the dorsal caudal fulcra (Fig. 2). There are portions of 12 dorsal caudal fulcra (dcf, Fig. 2) preserved, although these likely numbered more in life. There is a single ventral caudal fulcrum (vcf, Fig. 2). The caudal peduncle is slightly twisted but it appears to have been dorsoventrally flattened, as in Scaphirhynchus Heckel, 1836. Also as in the extant genus, the caudal peduncle is fully encased by distinct rows of scutes, including a row of lateral scutes (1s, Fig. 2) and two pairs of ventral caudal peduncle scutes that meet in the ventral midline (ventrolateral and ventromedial caudal peduncle scutes; vlps and vmps, respectively, Fig. 2). Only the right side of the dorsal surface of the caudal peduncle is exposed, so the exact arrangement of the scutes on the dorsal surface of the caudal peduncle is unclear. For further discussion of the caudal fin and skeleton of Acipenseriformes in general see Hilton (2004).

The internal skeletal supports are not preserved for either the dorsal or anal fin, and only the bases of the dorsal and anal fin rays are preserved. Wilimovsky (1956) reported two or three dorsal fin rays and about 28 anal fin rays. We believe that the anal fin described by Wilimovsky is, however, the dorsal fin (df, Fig. 1.3) based on the way that the caudal fin portion of the specimen fits onto the block with the body. The dorsal fin has a preserved base of about $9 \mathrm{~cm}$, but it is not complete enough for us to estimate its length or number of fin rays.

The preserved portions of the pectoral girdle include the left supracleithrum (scl, Fig. 1.1), portions of the left cleithrum (cl, Fig. 1.2), the ventral surface of the left clavicle [clv(1), Fig. 1.2; identified by Wilimovsky as the subopercle], and a fragment of the right clavicle $[\mathrm{clv}(\mathrm{r})$, Fig. 1.2]. The clavicle has radiating ornament and overlaps the anteroventral edge of the cleithrum, forming a cardiac shield. There is a distinct anterior process preserved on the left clavicle (Fig. 1.2), as is found in other sturgeons. The outline of the cleithrum is difficult to make out, but there does appear to be an exaggerated cleithral notch, as in extant sturgeons. Portions of two pectoral fins are preserved on the large block (pcf, Fig. 1.3), and the base of a pectoral fin spine is preserved on the block with the skull (pfs, Fig. 1.2). The internal skeleton of the pectoral girdle is not preserved and the number of fin rays could not be determined with confidence, although Wilimovsky (1956) reported about 34 pectoral fin rays.

Only a single pelvic fin is preserved and is separated from the body (plf, Fig. 1.3). Wilimovsky (1956) reported about 19-20 pelvic fin rays. Nothing is preserved of the pelvic girdle or fin supports.

A small, isolated piece of this specimen (Fig. 1.4) shows the remains of what may be two dorsal scutes, although this fragment could not be positioned in context with the rest of the specimen. Wilimovsky (1956) referred to these as lateral scutes. The preservation of the body scalation does not allow any detailed description, and only the posterior portion of the body is preserved at all (Fig. 1.3). The scales that cover the posterior portion of the body (trk, Fig. 1.3) appear to be small and somewhat elongate.

Material examined.-The holotype and only known specimen of $\dagger P$. squamosus (UMMP 22210), which is preserved in three main parts: 1) the skull (Fig. 1.1, 1.2); 2) portions of the trunk, including portions of the pectoral fins, pelvic fins, and the caudal region of the body (Fig. 1.3); and 3) portions of the caudal peduncle and fin (Fig. 2). The original portion of the caudal peduncle and fin is currently lost. A cast of this portion of the specimen, however, was available for this study. A small, isolated piece of this specimen preserves two or three dorsal scutes (Fig. 1.4).

Occurrence.-Hell Creek Formation; "about 24 miles SE of Fort Peck, Montana” (Wilimovsky, 1956: 1207); late Cretaceous; freshwater.

Discussion.-The poor condition of the specimen limits the ability to make comparisons with other specimens, and it is likely 

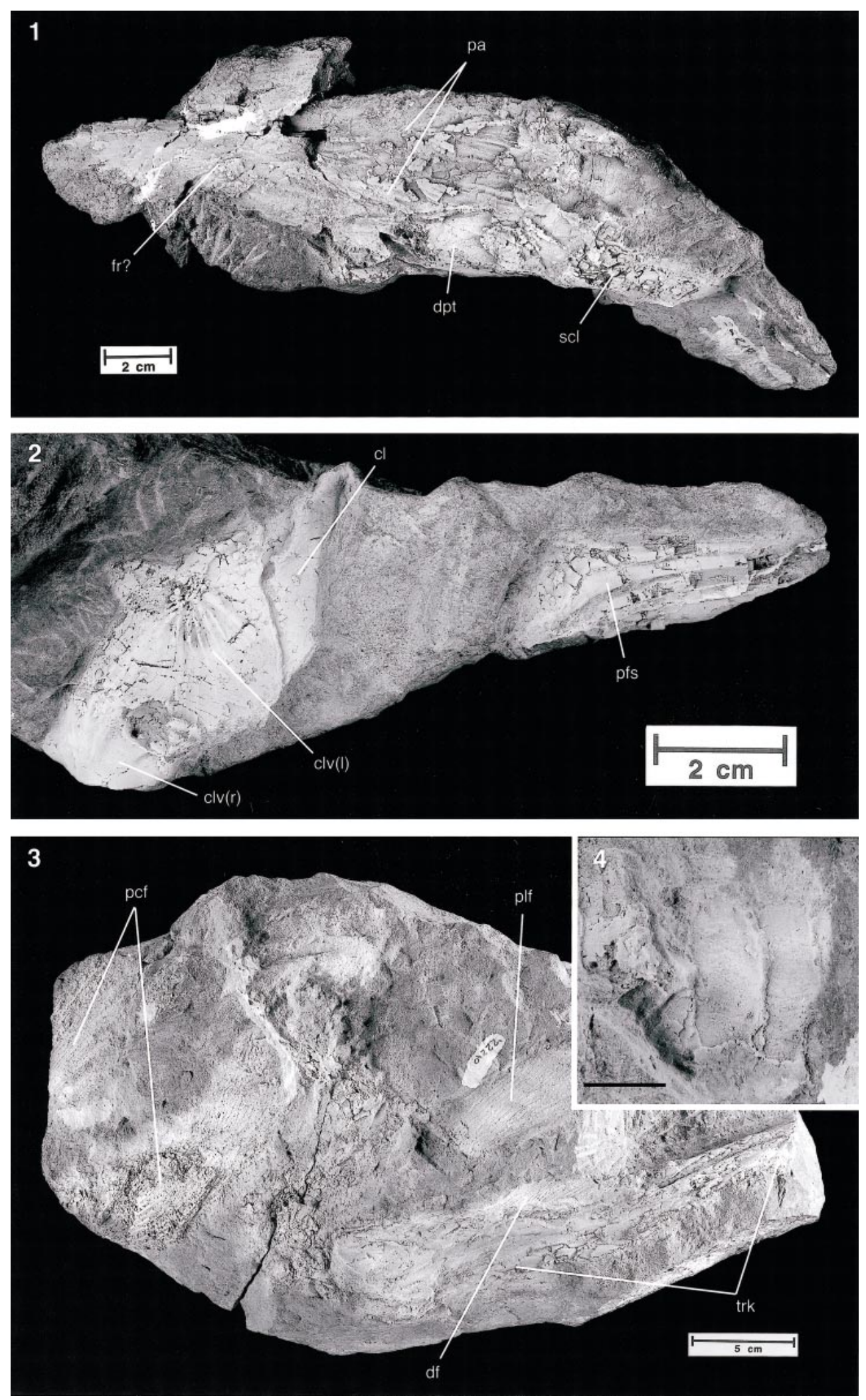

FIGURE 1-†Protoscaphirhynchus squamosus Wilimovsky, 1956, holotype (UMMP 22210). 1, Skull roof in dorsal view; anterior facing left. 2, Other side of the block with the skull roof, showing the ventral surface of the left clavicle and the proximal portion of the left fin spine; anterior facing left. 3, Posterior portion of body and portions of paired fins. Lines point to approximate centers of ossifications for individual bones, based on the ornamentation patterns. 4, Dorsal scutes; anterior facing left; scale bar $=1 \mathrm{~cm}$. Abbreviations: cl, cleithrum; clv(l); left clavicle; clv(r), right clavicle; df, dorsal fin; dpt, dermopterotic; fr, frontal; pa, parietals; pcf, pectoral fins; pfs, pectoral fin spine; plf, pelvic fin; scl, supracleithrum; trk, trunk. 

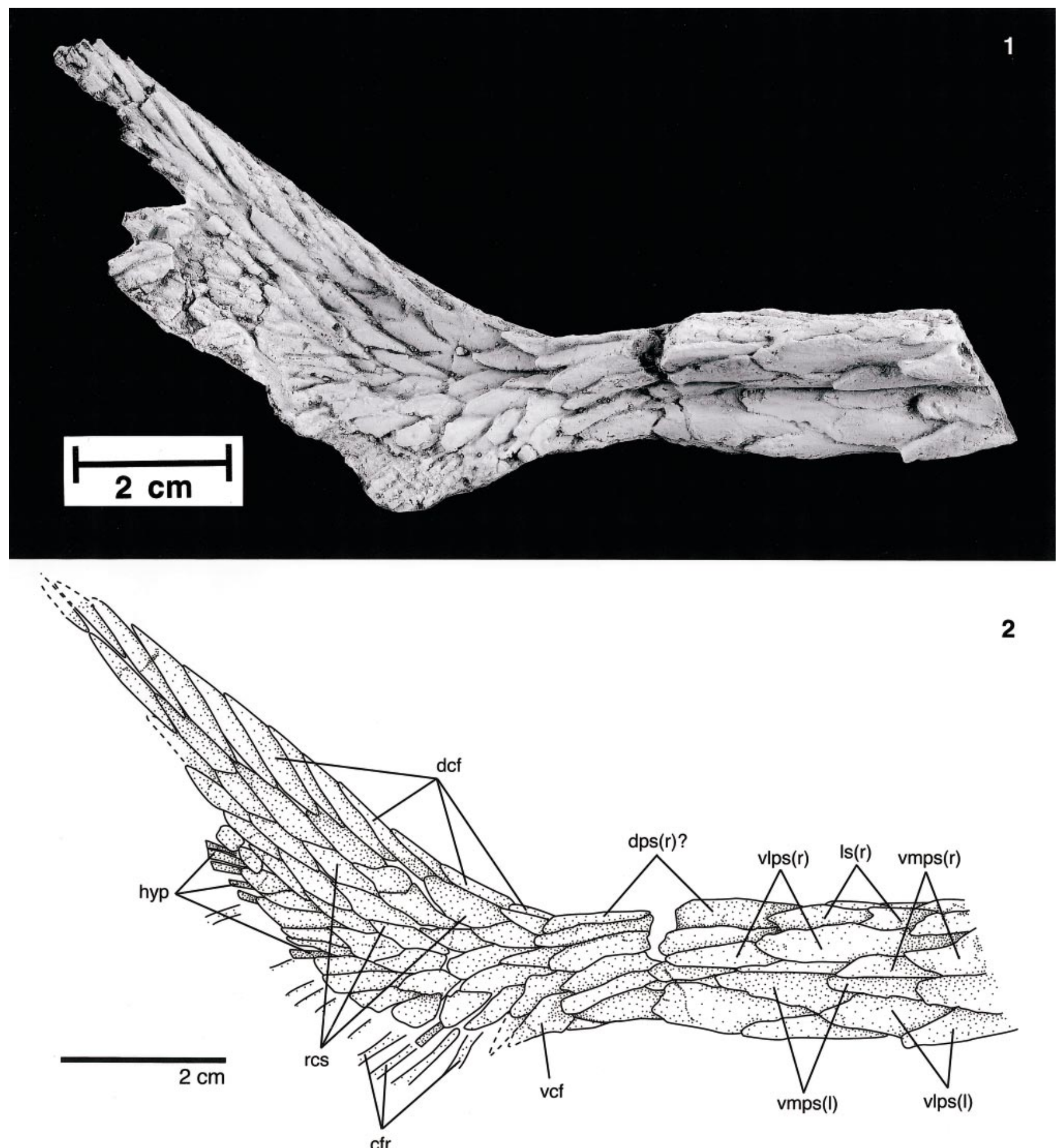

FIGURE 2-†Protoscaphirhynchus squamosus, holotype (UMMP 22210). 1, Photograph, and 2, line drawing of a cast of the caudal fin. Anterior facing right. Abbreviations: cfr, caudal fin rays; dcf, dorsal caudal fulcra; dps, dorsal caudal peduncle scute; hyp, hypural; 1, left; 1s, lateral scute; r, right; rcs, rhomboid caudal scale; vcf, ventral caudal fulcrum; vlps, ventrolateral caudal peduncle scute; vmps, ventromedial caudal peduncle scute.

that even additional specimens from even the same or nearby formations (e.g., the well-preserved specimen from Judith River described by Grande and Hilton, 2006) will not alleviate the situation with this problematic taxon. We suggest that this taxon should be treated as an inserted taxon (s. Grande and Bemis,
1998: 569) in future systematic analyses; characters preserved on the caudal fin portion of the specimen suggest possible affinities with Scaphirhynchus (e.g., Wilimovsky, 1956; Findeis, 1997).

Gardiner (1984) considered $\dagger$ Protoscaphirhynchus not to be a sturgeon, based on the presence of "ganoine-covered scales." 


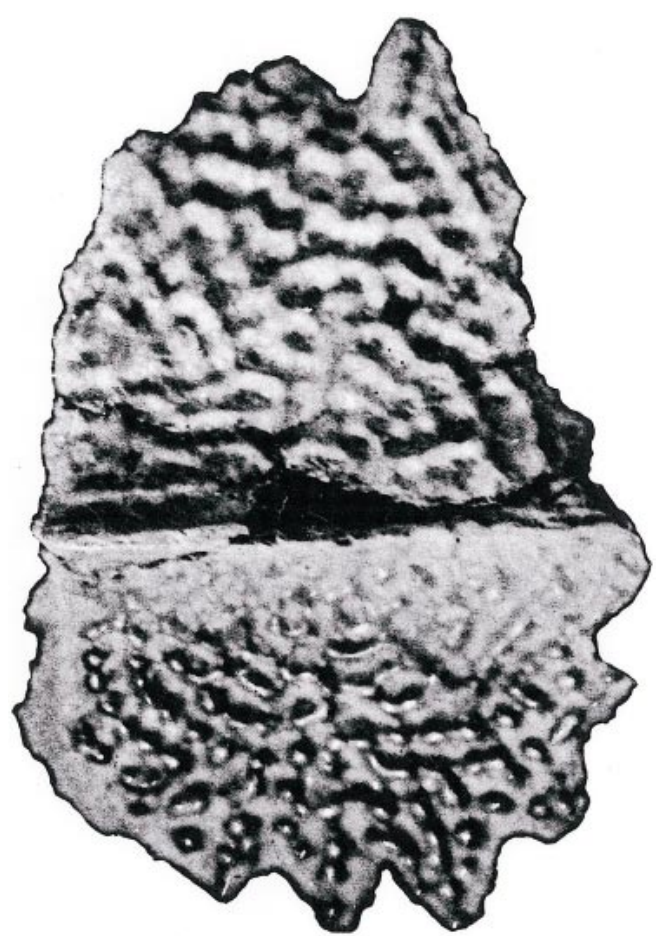

FIGURE 3- †Acipenser albertensis Lambe, 1902, holotype (CMN 1677), reproduced from Lambe (1902: pl. 21, fig. 9). This figure was originally published at the natural size of the specimen; it is enlarged in this reproduction (original is, as positioned on the page, $63 \mathrm{~mm}$ tall). Anterior facing left.

However, it was not demonstrated that the scalelike plates described by Wilimovsky (1956) are covered by ganoine (Bryant, 1989), and we regard $†$ Protoscaphirhynchus as a sturgeon due to the presence of a well-developed pectoral fin spine, a cardiac shield formed by ventral expansions of the cleithra, and the overall similarity of the caudal peduncle to that of Scaphirhynchus. $\dagger$ Protoscaphirhynchus was discovered, along with $\dagger$ Paleopsephurus wilsoni MacAlpin, 1941 (also MacAlpin, 1947; see Grande and Bemis, 1991), as associated material in the collection of a specimen of a hadrosaurid dinosaur (Wilimovsky, 1956). Coincidentally, the new taxon described by Grande and Hilton (2006) also was found in association with a hadrosaurid dinosaur.

\section{TAXA FROM NORTH AMERICA THAT ARE NOMINA DUBIA, REPRESENTING ACIPENSERIDAE INDETERMINATE GENUS AND SPECIES}

In this section, we review the nominal fossil sturgeon taxa from North America, which all are nomina dubia and regarded as Acipenseridae indeterminate genus and species. These taxa are discussed in alphabetical order by species epithet.

\section{$\dagger$ †ACIPENSER" ALBERTENSIS Lambe, 1902 Figure 3}

Acipenser albertensis LAMBE, 1902, p. 29, pl. 21, fig. 9. WiLimovsKy, 1956, p. 1206.

“Acipenser" albertensis LAMBE, 1902. BRyAnt, 1989, p. 17, figs. 7, 8.

Material examined.-Specimens labeled as such at UCMP.

Occurrence.- -Judith River Group (Oldman Formation?), Red Deer River, Alberta, Canada; late Cretaceous; fresh and brackish water (Osborn, 1902; Lambe, 1902; L. S. Russell, 1964).

Discussion.-The holotype (CMN 1677; Fig. 3) is a broken
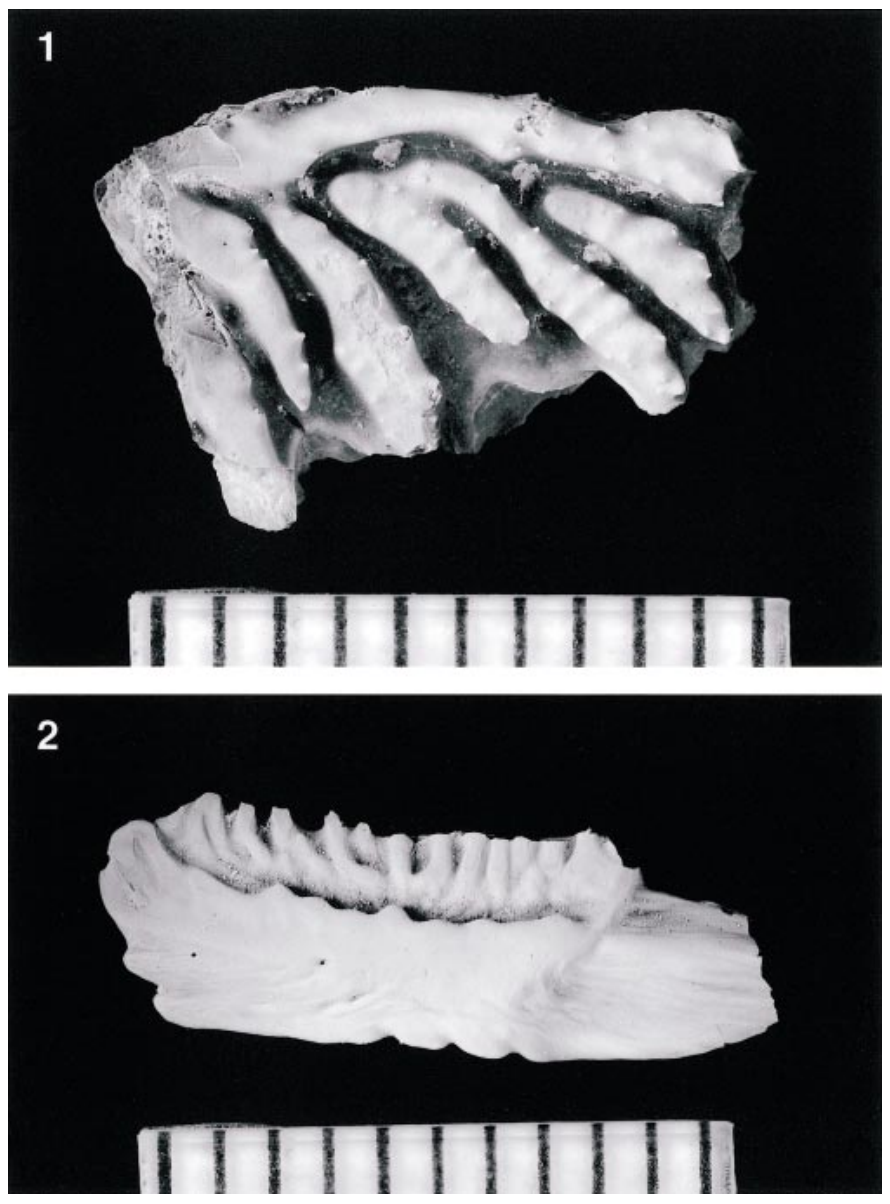

FIGURE 4-1, †Acipenser eruciferus (Cope, 1876), holotype (AMNH 7081); external view, orientation uncertain. 2 , †Ceratodus hieroglyphus Cope, 1876, holotype (AMNH 7080); considered also to be $†$. eruciferus by Estes (1964); view and orientation uncertain. Scale in millimeters.

dorsal scute. Lambe (1902: 29) wrote of $\dagger$ "A." albertensis: "The strongly keeled and highly ornamented shield ... apparently represents an ancient sturgeon." The scute illustrated by Lambe (1902: pl. 21, fig. 9; Fig. 3) is definitely from an acipenserid, but lacks any diagnostic features that separate it from any other member of the family, and therefore must be regarded as a nomen dubium.

Bryant (1989: figs. 7, 8) illustrated scutes and fin spines that she assigned to †"A." albertensis from the Hell Creek Formation.

$$
\begin{gathered}
\dagger \text { †ACIPENSER” } \\
\text { ERUCIFERUS (Cope, 1876) } \\
\text { Figure } 4.1
\end{gathered}
$$

Ceratodus eruciferus COPE, 1876, p. 259.

Ceratodus hieroglyphus COPE, 1876, p. 259. EsTES, 1964, p. 20.

Rhineastes eruciferus (COPE, 1876). LAMBE, 1902, p. 29.

Acipenser eruciferus (COPE, 1876). EstEs, 1964, p. 20, figs. 10, 11; Estes, Berberian, and Meszoely, 1969, p. 6, fig. 2.

"Acipenser" eruciferus (COPE, 1876). BRYANT, 1989, p. 15, fig. 6.

Material examined.-AMNH 7081, holotype, a fragment of ornamented dermal bone (Fig. 4.1) and other specimens labeled as such at MCZ.

Occurrence.-Lance Formation, Wyoming; late Cretaceous; subtropical freshwater (Estes, 1964). "Sediment of the Lance Formation was deposited as the last Mesozoic epicontinental sea retreated to the east and southeast. These western epeiric shoreline 
sediments were presumably deposited in lowland floodplain, swampy to marshy, densely vegetated, riparian environments" (Breithaupt, 1982: 127). This description agrees with that of Estes and Berberian (1970: 32), who described the Lance Formation as representing "a wooded swamp habitat, with small to medium sized watercourses and some ponding." Estes and Berberian (1970: 32) noted that the Bug Creek Anthills locality of the Tullock Formation (then considered to be part of the Hell Creek Formation), from which $\dagger$ "A." eruciferus has also been reported (e.g., Estes et al., 1969), "seems to be a major waterway issuing from such a wooded swamp [as from the Lance Formation]: similar habitats were available in or near both localities, but terrestrial and riparian habitats were restricted at $\mathrm{BCA}[=\mathrm{Bug}$ Creek Anthills], which may have been nearer the delta region of one of the major rivers emptying into the remnants of the late Cretaceous sea."

Discussion.-Cope (1876) described this species as a lungfish, $\dagger$ Ceratodus eruciferus Cope, 1876 , as well as a second taxon $(\dagger C$. hieroglyphus Cope, 1876; Fig. 4.2) based on fragmentary bones. Lambe (1902) placed these specimens in the catfish genus $\dagger R h i$ neastes Cope, 1872 (=†Astephus Cope, 1873, in part; see Grande and Lundberg, 1988), whereas Estes (1964) assigned these and other specimens (e.g., sturgeon scutes and pectoral fin spines) from the Lance Formation to the genus Acipenser. Estes et al. (1969) also described material of this taxon from the Hell Creek Formation (see below). Estes (1964: 21-22) noted that "All of the Lance formation spines are more dorsoventrally compressed than spines referred to Acipenser albertensis from the Oldman formation of Alberta, and on this basis they are referred to Cope's species A. eruciferus, though this may be only a slight geographical or temporal difference not of specific magnitude. The Judith River specimens are indistinguishable from those of the Lance formation." Breithaupt (1982: 132) referred to two specimens from this formation (UW 14266, fragment of pectoral fin ray; UW 14267, portion of a clavicle) as being "similar to Figure $2 d$ of Estes and others (1969)," although he declined to assign them to a species, citing the specimens in his faunal list as "cf. Acipenser sp." With no diagnostic features, †"A." eruciferus must be considered a nomen dubium.

Noting the infrequent recovery of acipenserid fossils in his localities, Breithaupt (1982: 144) noted that the "limited occurrence of sturgeon fossils, however, indicates that this anadromous, bottom-feeder was probably not a significant part of this fauna; it may represent an allochtonous taxon."

\section{†“ACIPENSER” ORNATUS Leidy, 1873a Figure 5}

Acipenser ornatus LeIDY, 1873a, p. 15. LEIDY, 1873c, p. 350, pl. 32, fig. 58. WiLIMOVSKY, 1956, p. 1206.

Acipenser oxyrhynchus Mitchell, 1815. PURDY ET AL., 2001, p. 161.

Material examined.-No material examined.

Occurrence.-Virginia, probably from the Calvert Formation; early to middle Miocene; marine.

Discussion.-Leidy (1873a: 15; this description also appeared verbatim in Leidy, 1873b) described this taxon as follows: "Founded on a dorso-lateral plate [=lateral scute] indicating an extinct species of sturgeon of medium size. The length of the plate is about $21 / 2$ inches; its breadth along the crest is an inch and three-fourths." Leidy (1873c: 350) wrote that $\dagger$ "A." ornatus "indicates a species about the size of our common sturgeon of the Delaware River. Though exhibiting no positive distinctive character, it probably pertained to a species now extinct." Based on his figure (Fig. 5), there are no diagnostic characters to distinguish this specimen from other acipenserids, so $\dagger$ " $A$." ornatus must be considered a nomen dubium.

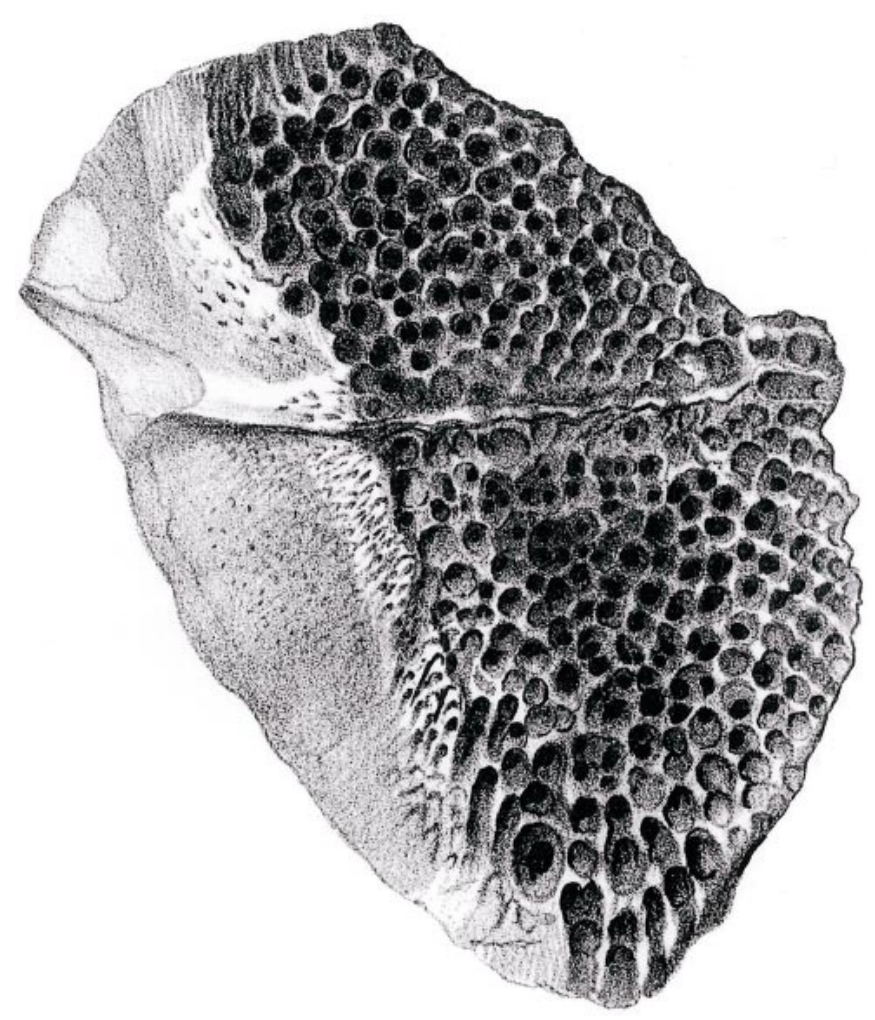

FIGURE 5- $\uparrow$ Acipenser ornatus Leidy, 1873a, holotype, reproduced from Leidy (1873a: pl. 32, fig. 58); the holotype was in a private collection and has been lost (Purdy et al., 2001). This figure was originally published at the natural size of the specimen; it is enlarged in this reproduction (original is, as positioned on the page, $58 \mathrm{~mm}$ tall). Anterior facing left.

The holotype (left lateral scute) that Leidy described and figured was in the private collection of Mr. C. M. Smith (Leidy, 1873a: pl. 32, fig. 58, reproduced here as Fig. 5), and is now considered lost (Purdy et al., 2001).

\section{OTHER MATERIALS FROM NORTH AMERICA REPRESENTING ACIPENSERIDAE INDETERMINATE GENUS AND SPECIES}

In the following sections we list records of fossil sturgeons from pre-Pleistocene formations of North America derived from firsthand observation of specimens. Additional records that are available in the literature but which remain unverified, primarily derived from published faunal lists, are listed in Table 1. While we have attempted to be as comprehensive as possible in our survey, there are likely gaps or omissions.

\section{RECORDS FROM THE LATE CRETACEOUS OF NORTH AMERICA}

Milk River Formation (Alberta; Santonian to Campanian; freshwater).-Acipenserid fossils from the Milk River Formation were recorded by D. A. Russell (1988). Payenberg et al. (2002) determined the Milk River Formation to be Santonian to early Campanian. Tenuously assigned specimens examined here include: TMP 89.89.3 (fragments of ornamented bone); TMP 91.105.20 (fragment of ornamented bone).

Judith River Group (s. Eberth and Hamblin, 1993) (Alberta, Saskatchewan, and Montana; middle to late Campanian; freshwater or estuarine).- - The nomenclature of the Judith River group has undergone several revisions recently. The Judith River Formation is continuous with what historically was called the Oldman Formation, and has been regarded as one and the same (e.g., 


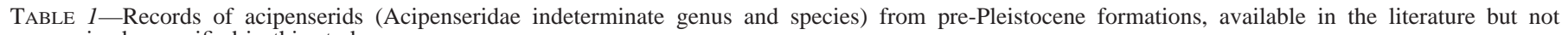
examined or verified in this study.

\begin{tabular}{|c|c|c|c|c|c|}
\hline Age & Formation & $\begin{array}{l}\text { Geographic } \\
\text { locality }\end{array}$ & $\begin{array}{l}\text { Paleo- } \\
\text { environment }\end{array}$ & $\begin{array}{l}\text { Type of specimen or } \\
\text { museum catalogue } \\
\text { number (? if unreported) }\end{array}$ & Reference(s) \\
\hline early Campanian & Merchantville & Delaware & marine & $?$ & $\begin{array}{l}\text { D. A. Russell (1988), } \\
\text { Lauginiger (1984) }\end{array}$ \\
\hline late Campanian & Marshalltown & New Jersey & marine, estuarine & NJSM 14521 & Grandstaff et al. (1992) \\
\hline $\begin{array}{l}\text { Campanian to } \\
\text { Maastrichtian }\end{array}$ & Mason River & $\begin{array}{l}\text { Northwest } \\
\text { Territories }\end{array}$ & marine & $\begin{array}{l}\text { undescribed material } \\
\text { at CMN }\end{array}$ & D. A. Russell (1988) \\
\hline $\begin{array}{l}\text { middle Campan- } \\
\text { ian to early } \\
\text { Maastrichtian }\end{array}$ & Williams Fork & Colorado & $\begin{array}{l}\text { marine, coastal } \\
\text { floodplain }\end{array}$ & $?$ & Archibald (1987) \\
\hline late Campanian & "Mesaverde" & Wyoming & $\begin{array}{l}\text { marine, coastal } \\
\text { floodplain }\end{array}$ & $?$ & Breithaupt (1985) \\
\hline $\begin{array}{l}\text { middle Maas- } \\
\text { trichtian }\end{array}$ & Horseshoe Canyon & Alberta & freshwater & $?$ & $\begin{array}{l}\text { D. A. Russell (1988), } \\
\text { Gardiner (1966) }\end{array}$ \\
\hline $\begin{array}{l}\text { middle Maas- } \\
\text { trichtian }\end{array}$ & Fruitland & New Mexico & brackish & $?$ & $\begin{array}{l}\text { D. A. Russell (1988), } \\
\text { Armstrong-Ziegler (1978) }\end{array}$ \\
\hline Maastrichtian & Edmonton & Alberta & brackish & $?$ & $\begin{array}{l}\text { Sternberg (1926), } \\
\text { L. S. Russell (1964) }\end{array}$ \\
\hline early Paleocene & Hornerstown & New Jersey & marine & $?$ & Gallagher (2002) \\
\hline $\begin{array}{l}\text { middle Paleo- } \\
\text { cene }\end{array}$ & Tongue River & Montana & freshwater & scutes (e.g., PU 19760) & Estes (1976) \\
\hline middle Miocene & Gatún Formation & Panama & marine & fragmentary scutes & Gillette (1984) \\
\hline
\end{tabular}

Dodson, 1983). Eberth and Hamblin (1993) recently gave an account of the stratigraphy of the Judith River group, and divided what had been a single formation (Judith River Formation; e.g., McLean, 1971) into three distinct formations: the Foremost Formation; the Oldman Formation; and the Dinosaur Park Formation (oldest to youngest, respectively).

Brinkman (1990) recorded several specimens of Acipenser from his microvertebrate sites within the Judith River Formation and Beavan and Russell (1999: fig. 4.15, 4.16) figured a fragment of dermal bone and a broken fin spine from the Dinosaur Park Formation portion of the Judith River group.

We present all specimens from formations within the Judith River Group that we examined in this section. A large number of specimens from the Judith River Formation (s. McLean, 1971) are housed at TMP, and consist of fragments of scutes and other ornamented dermal bone (e.g., TMP 89.50.7; TMP 94.12.949; TMP 90.36.121) and fin spines (e.g., TMP 81.39.4; TMP 74.10.34; TMP 89.36.135; TMP 89.2.21; TMP 90.50.160) and an incomplete skull roof (TMP 94.360.1). A single individual of a new, well-preserved taxon (MOR 1184) has also been recovered from the Judith River Formation; Grande and Hilton (2006) present a detailed description of this specimen. Other Judith River specimens examined here include: ANSP 17779 (a dorsal scute) and ANSP 17888 (fragments of a fin spine); and uncatalogued specimens at AMNH (fragments of ornamented dermal bone). Other noteworthy specimens from formations within the Judith River Group include UALVP 94 (a pectoral fin spine) from the Oldman Formation and TMP 96.150.1 (a large, incomplete skeleton consisting of portions of the skull and pectoral girdle, five rows of scutes, and portions of the median and paired fins) from the Dinosaur Park Formation. Large collections of scutes and pectoral fin spines from the Dinosaur Park Formation are also housed at TMP.

Prince Creek Formation (Alaska; early Maastrichtian; freshwater).Clemens and Nelms (1993: 504) referred to a "sturgeonlike" fish present in this formation, but provided no further description. The specimen (UAF AK-137V-1) is a well-preserved but isolated right supracleithrum of an acipenserid.

Lance Formation (Wyoming; late Maastrichtian; freshwater).- This is the type formation for $\dagger$ "A." eruciferus, although specimens from this locality are better interpreted as Acipenseridae indeterminate genus and species (see above). Estes (1964) illustrated acipenserid pectoral fin spines and scutes from this formation. In addition to the type specimen of $\uparrow$ "A." eruciferus (Fig. 4), specimens from the Lance Formation examined in the present study include AMNH 4985 and AMNH 4986 (fragments of dermal bone).

Hell Creek Formation (Montana; late Maastrichtian; freshwater).-There have been many reports of sturgeon fossils from the Hell Creek Formation, consisting mostly of isolated scutes and pectoral fin spines (e.g., see Bryant, 1989). Specimens of sturgeons from Hell Creek examined here include: USNM 339886 (fragments of fin spines); LACM 40162 (fragment of a fin spine); LACM 35017 (fragments of fin spines and ornamented dermal bone); and many catalogued and uncatalogued specimens at UCMP (isolated and fragmentary fin spines and ornamented dermal bone; Fig. 6.1-6.3). Perhaps the most striking specimen from Hell Creek is UCMP 129670, which is a partial skeleton including most of the dermal elements of the pectoral girdles and fins, the posteriormost part of the skull, and five rows of scutes from the anterior portion of the body (Fig. 6.4). Hell Creek Formation is also the type locality of $\dagger$ Protoscaphirhynchus squamosus (see above).

RECORDS FROM THE PALEOCENE OF NORTH AMERICA

Tullock Formation (Montana; early Paleocene; freshwater).- The Tullock Formation lies directly above the Hell Creek Formation. Many acipenserid specimens are known from the Tullock Formation, although they are typically highly fragmentary pieces of dermal bone. Large collections of acipenserid material from the Tullock Formation are housed at MCZ and UCMP (e.g., Estes, 1964; Estes et al., 1969; Estes and Berberian, 1970; Bryant, 1989) and we examined numerous specimens in these collections. Several Tullock Formation sites (e.g., Bug Creek Anthills, Bug Creek West, and Harbicht Hill) at one time were considered to be Late Cretaceous in age (i.e., part of the Hell Creek Formation) due to the presence of Late Cretaceous mammal and dinosaur bones. However, these localities have been determined to be $\mathrm{Pa}$ leocene (Puercan) through palynology by Lofgren (1995).

RECORDS FROM THE EOCENE OF NORTH AMERICA

No North American fossil sturgeons from the Eocene were found in our survey of collections and literature. A single specimen from the Eocene Wasatch Formation (Wyoming) is catalogued as Acipenser sp. at UCMP (UCMP 114526); this specimen 

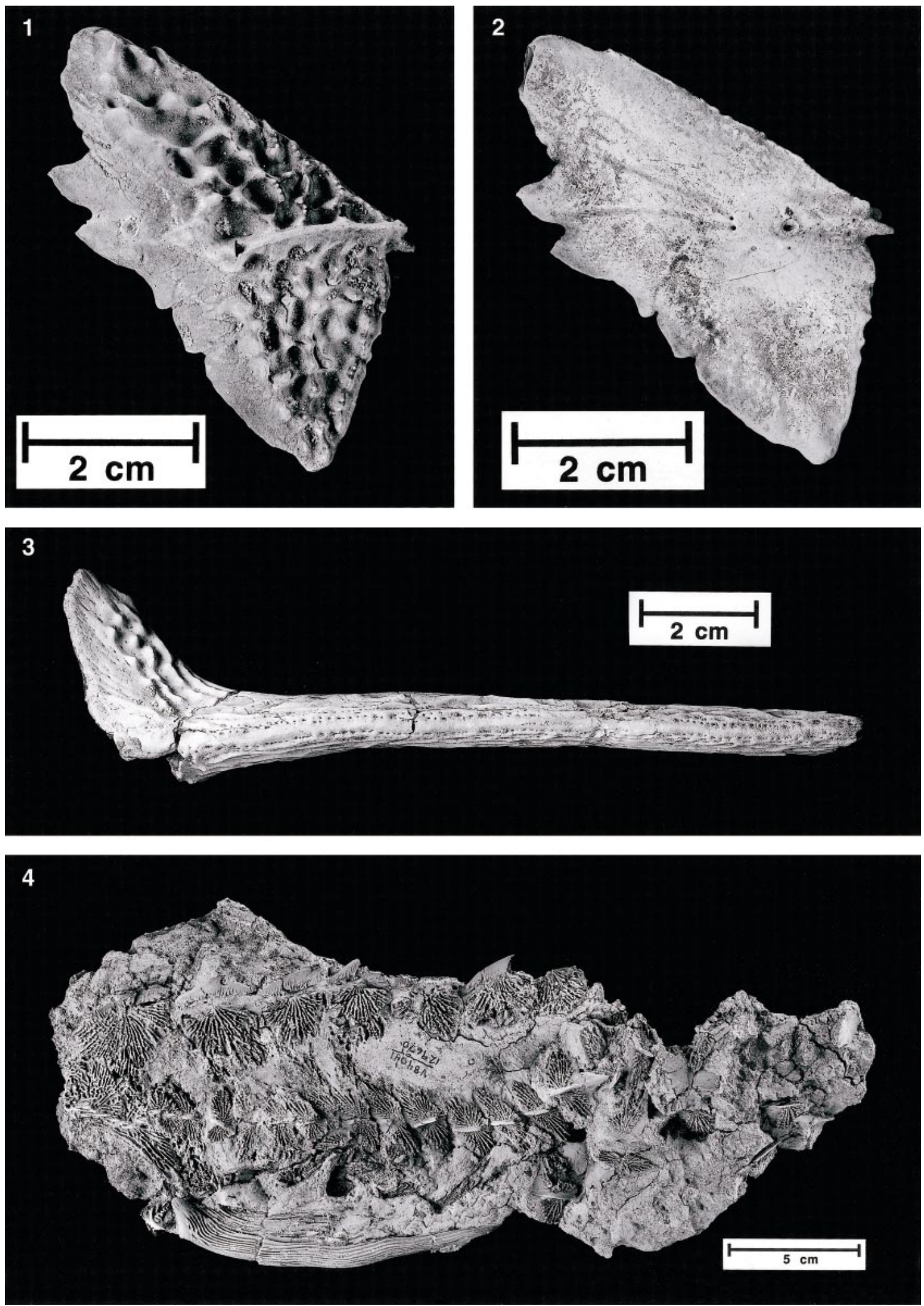

FIGURE 6-Acipenseridae indeterminate genus and species from the Hell Creek Formation (late Cretaceous). Isolated lateral scute (UCMP 146427) in 1, lateral view (image reversed so that anterior facing left) and 2, medial view (anterior faces left). 3, Isolated pectoral fin spine (UCMP 115962); anterior facing left. 4, Pectoral girdle and anterior portion of the trunk (UCMP 129670); anterior facing left. 

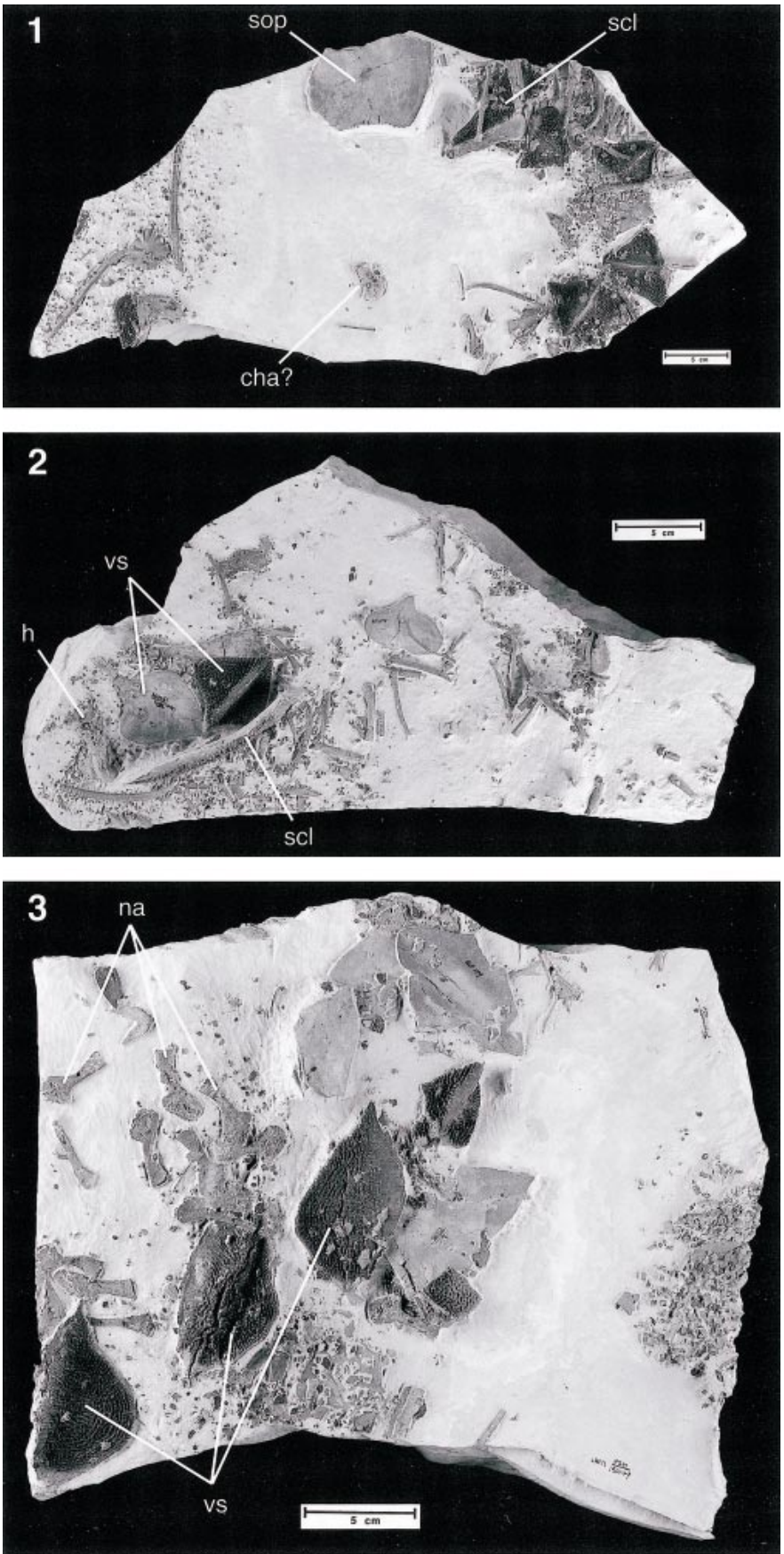

FIGURE 7-Acipenseridae indeterminate genus and species from the Monterey Formation (Miocene) (LACM 7501). Three pieces (1-3) of a single large individual. Abbreviations: cha, anterior ceratohyal; $h$, hyomandibula; na, neural arch; scl, supracleithrum; sop, subopercle; vs, ventral scute.

could not be located during a visit to the collection by EJH in March 2003. S. Cumbaa (personal commun., 2003) informed us of CMN specimens from the Eocene of Saskatchewan that are potentially acipenserid; these specimens were not examined.

RECORDS FROM THE OLIGOCENE OF NORTH AMERICA

No North American Oligocene fossil sturgeons were found in our survey of collections and literature.
RECORDS FROM THE MIOCENE OF NORTH AMERICA

Round Mountain Silt (California; early to middle Miocene; marine).-Bartow and McDougall (1984) determined the Round Mountain Silt to be middle Miocene, possibly extending back to the late early Miocene (see also Addicott, 1970). Acipenserid specimens examined from this formation include: LACM 47035 (scute; there is also another uncatalogued scute at LACM with the same locality and collection data as LACM 47035); LACM 115197 (a median fin fulcrum or scute); LACM 97596 (dermal bone, possibly part of the dermopterotic); and LACM 6688 (lateral scute).

Calvert Formation (Maryland; early to middle Miocene; marine).- Stratigraphic information about this formation was summarized by Gibson (1983). This formation extends into Virginia and is likely the source of Leidy's (1873a) †"A." ornatus (see above, Fig. 5). Specimens examined here include: ANSP 19988; USNM 438665 (a lateral scute); and USNM 25880 (pieces of dermal bone).

Monterey Formation (California; early to late Miocene; marine).- One specimen from the Monterey Formation was examined here: LACM 150079 (a disarticulated partial skeleton, including portions of the hyoid and opercular series, scutes, axial skeletal elements, pectoral girdle bones, and fin rays; Fig. 7). This specimen was collected in Mission Viejo, Orange County, California. The depositional environment of other portions of the Monterey Formation have been described by Lagoe (1985), Chang et al. (1998), and John et al. (2002), among others.

Puente Formation (California; late Miocene; marine).-Specimens examined here include numerous catalogued and uncatalogued specimens at UCMP. An additional specimen from this formation, a subopercle from a large individual preserved as part and counterpart, is curated at the Ralph B. Clark Interpretive Center (catalogue number 3819a, b) in Buena Park, California. For information on the stratigraphy of the Puente Formation, see Critelli et al. (1995).

Capistrano Formation (California; late Miocene to early Pliocene; marine).- Specimens from the Capistrano Formation examined here include: LACM 40166 (scute); LACM 40154 (a ventral scute); LACM 128782 (fragment of dermal bone); LACM 50601 (fragment of ornamented dermal bone); LACM 40155 (fragment of ornamented dermal bone); LACM 50662 (fragment of ornamented dermal bone); LACM 40736 (fragments of ornamented dermal bone); also uncatalogued material at LACM from LACM locality 4438 (Eastend Mission Viejo Dam).

\section{RECORDS FROM THE PLIOCENE OF NORTH AMERICA}

Yorktown Formation (North Carolina; early Pliocene; marine).- Stratigraphic information about this formation was summarized by Gibson (1983). The specimens from this formation come from the Lee Creek Mine, near the town of Aurora, North Carolina (see Purdy et al., 2001 for discussion of the locality and its fish fauna). Sturgeons are very common at this site. Purdy et al. (2001: 161) cited "several thousand fragments" that they identified as Acipenser cf. A. oxyrhynchus Mitchell, 1815. Specimens examined here include: ANSP 21380; LACM 127932 (ornamented dermal bone); as well as several of the USNM specimens referred to by Purdy et al. (2001).

San Joaquin Formation (California; Pliocene; marine).-Specimens from the San Joaquin Formation examined here include: LACM 138554 (a scute) and uncatalogued material at LACM with the same locality and collection data (fragmentary ornamented bones, scutes, fulcra, and a portion of a pectoral fin spine). 
NORTH AMERICAN TAXON INCORRECTLY DESCRIBED AS BELONGING TO ACIPENSERIDAE AND LATER REMOVED

$†$ Propenser heWletTi Applegate, 1970

Propenser hewletti ApPlegAte, 1970, p. 399, figs. 180-185. Hadrodus hewletti (APPlEGATE). Bell, 1986, p. 1,120.

Material examined.-FMNH PF288 (a plate of dermal bone that Applegate, 1970 thought might belong to the holotype).

Occurrence.-Selma Formation, Green County, Alabama, USA; Late Cretaceous (Pierre Shale); marine (see Zangerl, 1948).

Discussion.-The holotype (and other referred material) was listed by Applegate (1970) as a specimen in the Alabama Geological Survey (Tuscaloosa) collection. Applegate (1970) did not provide a catalogue number for the holotype, which includes portions of the skull, scutes, shoulder girdle, fin spines, and vertebrae. We did not examine this specimen. This taxon has been reinterpreted as portions of a coelacanth and a pycnodont (e.g., see Bell, 1986; Bemis et al., 1997).

\section{CONCLUSIONS}

The fossil record of acipenserids diagnosable to the level of species, or indeed to any taxonomic level lower than family, is almost nonexistent in North America. However, fossilized remains of the family are found through much of the fossil record since the late Cretaceous. A major gap in the record is during the Eocene and Oligocene, for which there are few, if any, specimens available. This is surprising, particularly given the well-preserved freshwater environments that are known from those times that have produced other acipenseriform taxa (e.g., the polyodontid $\nmid$ Crossopholis Cope, 1883 from the Eocene Green River Formation of southwestern Wyoming; Grande, 1984, 2001; Grande and Bemis, 1991). It is also interesting to note that European deposits have yielded acipenserid specimens from these time periods [e.g., †"A." lemoinei (Priem, 1901), see Priem, 1904, and $\uparrow " A$." parisiensis Priem, 1908 from the early Eocene and Oligocene of France, respectively; and $\dagger$ "A." toliapicus Agassiz, 1844 from the early Eocene London Clay, Isle of Sheppy, England]. The figures of $\dagger$ "A." lemione $i$ and $\dagger$ "A." parisiensis published by Priem (1901, 1908, respectively) and examination of the holotype of Agassiz's +"A." toliapicus (an isolated dorsal scute, BMNH P529) suggest that these taxa are also nomina dubia and should be regarded as Acipenseridae indeterminate genus and species.

As shown above, the fossilized remains of most sturgeons are very fragmentary in nature, typically consisting of pieces of isolated, broken dermal bone, fin spines, and other elements that do not preserve species- or genus-level diagnostic characters (e.g., meristic or morphometric data). Even the most complete specimens that we examined in our survey of collections do not allow for finer levels of taxonomic identification. This is the product of several factors. The skeleton of acipenserids is prone to disarticulation before fossilization can occur. The internal skeleton is largely cartilaginous and the ossified portions (e.g., neural arches, ribs, etc.) are likely to be disassociated from the rest of the skeleton, if preserved at all. Even the exoskeleton is likely to be disarticulated before fossilization because the bones that comprise it (e.g., scutes, dermal skull, etc.) are not tightly sutured together (i.e., they articulate through overlapping sutures), and may be more likely to disarticulate before fossilization than a skeleton formed by interlocking sutures. Additionally, most modern sturgeons inhabit high-energy environments, such as large riverine and nearshore marine habitats. If fossil sturgeons inhabited similar environments, as is suggested by the paleoenvironments of the localities from which they are known (see above), this would increase the likelihood that the skeleton of a sturgeon would be disarticulated before fossilization can occur. Such taphonomic factors limit the probability that articulated fossils will be discovered.

Our inability to identify fossilized sturgeons more precisely than Acipenseridae indeterminate also stems from a lack of known characters to differentially diagnose extant sturgeon genera. Most problematic is the genus Acipenser, the largest genus of sturgeons, which has no known osteological synapomorphies (e.g., Findeis, 1997) and historically has been a "wastebasket" taxon. The monophyly of Acipenser and Pseudoscaphirhynchus Nikolskii, 1900 has been questioned in recent studies (e.g., Mayden and Kuhajda, 1996; Birstein et al., 2002; see discussion by Hilton, 2005), and no morphological study has included all species of sturgeons. The lack of resolution of the interrelationships among living genera of sturgeons in our preliminary systematic analyses (e.g., Grande and Hilton, 2006) underscores this problem. Specifically, we still do not have solid hypotheses of how the two species of Huso Brandt, 1869 are related to other sturgeons, nor do we understand the characters that may define the genus Acipenser, which are necessary to establish its taxonomic limits. Certain taxa, such as Scaphirhynchus, do have a certain gestalt to their ornamentation, for instance, that may allow for recognition in the fossil record. However, we have not been able to satisfactorily define characters from the portions of the skeleton of sturgeons that are typically preserved as fossils (i.e., scutes and pectoral fin spines) that usefully separate all of the currently recognized genera.

\section{ACKNOWLEDGMENTS}

Many curators, collection managers, and collections staff have helped during visits to collections, with loans of specimens, and information on specimens in their care. For this we offer our sincere thanks: J. Maisey and I. Rutzky (AMNH-Vertebrate Paleontology); E. B. Daeschler (ANSP-Department of Paleontology); P. L. Forey (BMNH); S. Cumbaa (CMN); L. Barnes, J. D. Stewart (formerly), and S. McLeod (LACM-Vertebrate Paleontology); F. Jenkins and C. Schaff (MCZ-Paleontology); J. Horner (MOR); L. Babilonia (Ralph B. Clark Interpretive Center, Buena Park, California); A. Neuman and J. D. Gardiner (TMP); M. V. H. Wilson (UALVP); W. Clemens (retired), M. Goodwin, K. Padian, and P. Holroyd (UCMP); G. Smith and G. Gunnell (UMMP); and R. Purdy (USNM-Vertebrate Paleontology). We thank J. Weinstein and K. Bean for photographic assistance and K. Shimada for directing our attention to the paper by Bell (1986). The comments and suggestions of S. L. Cumbaa and M. V. H. Wilson were greatly appreciated.

This research has been funded by the National Science Foundation (NSF) DEB-0128929 (to Hilton, Grande, and Bemis) and DEB-0414552 (to Hilton and Grande).

\section{REFERENCES}

AdDicotT, W. O. 1970. Miocene gastropods and biostratigraphy of the Kern River area, California. United States Geological Survey Professional Papers, 642:1-174.

AgAssiz, L. 1833-1844. Recherchers sur les Poisson Fossiles. Pettipierre et Prince, Neuchâtel. 5 vols., 1,420 p. with supplements. (The portion of Agassiz's work referred to in this paper was published in 1844, according to W. H. Brown in Woodward and Sherborn, 1890.)

Applegate, S. P. 1970. The vertebrate fauna of the Selma formation of Alabama, Pt. VIII, The Fishes. Fieldiana (Geology) Memoir, 3:383433.

Archibald, J. D. 1987. Late Cretaceous (Judithian and Edmontonian) vertebrates and geology of the Williams Fork Formation, N.W. Colorado. Occasional Papers of the Tyrrell Museum of Palaeontology, 3:711.

Armstrong-ZiEgler, J. G. 1978. An aniliid snake and associated vertebrates from the Campanian of New Mexico. Journal of Paleontology, 52:480-483.

Bartow, J. A., AND K. McDougall. 1984. Tertiary stratigraphy of the 
southeastern San Joaquin Valley, California. United States Geological Survey Bulletin, 1529-J:1-41.

Beavan, N. R., AND A. P. Russell. 1999. An elasmobranch assemblage from the terrestrial-marine transitional lethbridge coal zone (Dinosaur Park Formation: Upper Campanian), Alberta, Canada. Journal of Paleontology, 73:494-503.

BELL JR., G. L. 1986. A pycnodont fish from the Upper Cretaceous of Alabama. Journal of Paleontology, 60:1120-1126.

Bemis, W. E., E. K. Findeis, and L. Grande. 1997. An overview of Acipenseriformes. Environmental Biology of Fishes, 48:25-72.

BERG, L. S. 1940. Classification of fishes, both Recent and fossil. Travaux de l'Institut Zoologique de l'Académie des Sciences de l'URSS. Vol. 5. 345 p. (In Russian; reprint with English translation of text published by J. W. Edwards, Ann Arbor, 1947.)

Birstein, V. J., P. Doukakis, AND R. DeSalle. 2002. Molecular phylogeny of Acipenseridae: Nonmonophyly of Scaphirhynchinae. Copeia, 2002:287-301.

Bonaparte, C. L. 1831. Saggio di una distribuzione metodico degli animali vertebrati. Giornale Arcadico di Scienze, Lettere ad Arti, 49:177.

BRANDT, J. F. 1869. Einige worte über die europaich-asiatischen Störarten (Sturionides). Mélanges Biologique, 7:110-116.

Breithaupt, B. H. 1982. Paleontology and paleoecology of the Lance Formation (Maastrichthian), east flank of Rock Springs Uplift, Sweetwater County, Wyoming. Contributions to Geology, University of Wyoming, 21:123-151.

BREITHAUPT, B. H. 1985. Nonmammalian vertebrate faunas from the Late Cretaceous of Wyoming. Thirty-sixth Annual Field Conference, Wyoming Geological Association Guidebook, p. 159-175.

BRINKMAN, D. 1990. Paleoecology of the Judith River Formation (Campanian) of Dinosaur Provincial Park, Alberta, Canada: Evidence from vertebrate microfossil localities. Palaeogeography, Palaeoclimatology, Palaeoecology, 78:37-54.

BRYANT, L. J. 1989. Non-dinosaurian lower vertebrates across the Cretaceous-Tertiary boundary in northeastern Montana. University of California Publications in Geological Sciences, 134:1-107.

Chang, A. S., K. A. Grimm, And L. D. White. 1998. Diatomaceous sediments from the Miocene Monterey Formation: A lamina-scale investigation of biological, ecological, and sedimentary processes. Palaios, 13:439-458.

Choudhury, A., And T. A. Dick. 1998. The historical biogeography of sturgeons (Osteichthyes: Acipenseridae): A synthesis of phylogenetics, palaeontology and palaeogeography. Journal of Biogeography, 25:623640.

Clemens, W. A., And L. G. Nelms. 1993. Paleoecological implications of Alaskan terrestrial vertebrate fauna in latest Cretaceous time at high paleolatitudes. Geology, 21:503-506.

Cope, E. D. 1871. Observations on the systematic relations of the fishes. American Naturalist, 5:579-593.

Cope, E. D. 1872. Notices of new Vertebrata from the upper waters of Bitter Creek, Wyoming Territory. Proceedings of the American Philosophical Society for 1871, 12:483-486.

COPE, E. D. 1873. On the extinct Vertebrata of the Eocene of Wyoming observed by the expedition of 1872, with notes on the geology. Sixth Report, U.S. Geological and Geographical Survey of the Territories, p. 545-649.

Cope, E. D. 1876. Description of some vertebrate remains from the Fort Union beds of Montana. Proceeding of the Academy of Natural Sciences of Philadelphia, 1876:248-261.

Cope, E. D. 1883. A new chondrostean from the Eocene. American Naturalist, 17:1152-1153.

Cope, E. D. 1887. Zittel's Manual of Palaeontology. American Naturalist, 21:1014-1019. (A review of the above work of Professor Zittel, containing a classification of the teleostomous fishes.)

Critelli, S., P. E. Rumelhart, AND R. V. Ingersoll. 1995. Petrofacies and provenance of the Puente Formation (Middle to Upper Miocene), Los Angeles Basin, southern California: Implications for rapid uplift and accumulation rates. Journal of Sedimentary Research, Section A: Sedimentary Petrology and Processes, 65:656-667.

Dodson, P. 1983. A faunal review of the Judith River (Oldman) Formation, Dinosaur Provincial Park, Alberta. The Mosasaur, 1:89-118.

Eberth, D. A., And A. P. Hamblin. 1993. Tectonic, stratigraphic, and sedimontologic significance of a regional discontinuity in the upper
Judith River Group (Belly River wedge) of southern Alberta, Saskatchewan, and northern Montana. Canadian Journal of Earth Sciences, 30: 174-200.

Estes, R. 1964. Fossil vertebrates from the Late Cretaceous Lance Formation eastern Wyoming. University of California Publications in Geological Sciences, 49:1-180.

Estes, R. 1976. Middle Paleocene lower vertebrates from the Tongue River Formation, southeastern Montana. Journal of Paleontology, 50: 500-520.

Estes, R., AND P. Berberian. 1970. Paleoecology of a Late Cretaceous vertebrate community from Montana. Breviora, Number 343, $35 \mathrm{p}$.

Estes, R., P. Berberian, And C. A. M. Meszoely. 1969. Lower vertebrates from the Late Cretaceous Hell Creek Formation, McCone County, Montana. Breviora, Number 337, 33 p.

FINDEIS, E. K. 1997. Osteology and phylogenetic relationships of recent sturgeons. Environmental Biology of Fishes, 48:73-126.

FOLLETT, W. I. 1975. Fish remains from the West Berkeley shellmound (CA-Ala-307), Alameda County, California. Appendix B of West Berkeley (CA-Ala-307): A culturally stratified shellmound on the east shore of San Francisco Bay. Contributions of the University of California Archaeological Research Facility, 29:71-98.

Gallagher, W. B. 2002. Faunal changes across the Cretaceous-Tertiary (K-T) boundary in the Atlantic coastal plain of New Jersey: Restructuring the marine community after the K-T mass-extinction event, $\mathrm{p}$. 291-301. In C. Koeberl and K. G. MacLeod (eds.), Catastrophic Events and Mass Extinctions: Impacts and Beyond. Geological Society of America Special Paper, 356.

Gardiner, B. G. 1966. Catalogue of Canadian fossil fishes. Royal Ontario Museum Contributions in Life Sciences, 68:1-154.

Gardiner, B. G. 1984. Sturgeons as living fossils, p. 148-152. In N. Eldridge and S. M. Stanley (eds.), Living Fossils. Springer Verlag, New York.

Gibson, T. G. 1983. Stratigraphy of Miocene through Lower Pleistocene strata of the United States central Atlantic coastal plain. Smithsonian Contributions to Paleobiology, 53:35-80.

Gillette, D. D. 1984. A marine ichthyofauna from the Miocene of Panama, and the Tertiary Caribbean faunal province. Journal of Vertebrate Paleontology, 4:172-186.

Gobalet, K. W. 1990. Fish remains from nine archaeological sites in Richmond and San Pablo, Contra Costa County, California. California Fish and Game, 76:234-243.

Grande, L. 1984. Paleontology of the Green River Formation, with a review of the fish fauna. Bulletin of the Geological Survey of Wyoming, 63:1-333.

GRANDE, L. 2001. An updated review of the fish faunas from the Green River Formation, the world's most productive freshwater lagerstätten, p. 1-38. In G. F. Gunnell (ed.), Eocene Biodiversity: Unusual Occurrences and Rarely Sampled Habitats. Kluwer Academic/Plenum Publishers, New York.

Grande, L., AND W. E. Bemis. 1991. Osteology and phylogenetic relationships of fossil and Recent paddlefishes (Polyodontidae) with comments on the interrelationships of Acipenseriformes. Society of Vertebrate Paleontology Memoir, Number 1, 121 p.; supplement to Journal of Vertebrate Paleontology, 11(1).

GRANDE, L., AND W. E. BEMIS. 1996. Interrelationships of Acipenseriformes, with comments on "Chondrostei," p. 85-115. In M. L. J. Stiassny, L. R. Parenti, and G. D. Johnson (eds.), Interrelationships of Fishes. Academic Press, San Diego.

Grande, L., AND W. E. BEMIS. 1998. A comprehensive phylogenetic study of amiid fishes (Amiidae) based on comparative skeletal anatomy. An empirical search for interconnected patterns of natural history. Society of Vertebrate Paleontology Memoir, Number 4, 690 p.; supplement to Journal of Vertebrate Paleontology, 18(1).

GRANDE, L., AND E. J. HiLton. 2006. An exquisitely preserved skeleton representing a primitive sturgeon from the Upper Cretaceous Judith River Formation of Montana (Acipenseriformes: Acipenseridae: n.gen. and sp.). Memoir of the Journal of Paleontology, 39 p.

GRANDE, L., AND J. G. LUNDBERG. 1988. Revision and redescription of the genus $\dagger$ Astephus (Siluriformes: Ictaluridae) with a discussion of its phylogenetic relationships. Journal of Vertebrate Paleontology, 8:139171.

Grande, L., F. Jin, Y. Yabumoto, And W. E. Bemis. 2002. †Protopsephurus liui, a well-preserved primitive paddlefish (Acipenseriformes: 
Polyodontidae) from the Early Cretaceous of China. Journal of Vertebrate Paleontology, 22:209-237.

Grandstaff, B. S., D. C. Parris, R. K. Denton JR., and W. B. GalLAGHER. 1992. Alphadon (Marsupialia) and Multituberculata (Allotheria) in the Cretaceous of eastern North America. Journal of Vertebrate Paleontology, 12:217-222.

HeCKEL, J. J. 1836. Scaphirhynchus, eine neue fischgattung aus ordnung der Chondropterygier mit freien kiemen. Annalen des Wiener Museum der Naturgeschichte, 1:68-78.

Hilton, E. J. 2004. The caudal skeleton of Acipenseriformes (Actinopterygii: Chondrostei): Recent advances and new observations, p. 599617. In G. Arratia, M. V. H. Wilson, and R. Cloutier (eds.), Recent Advances in the Origin and Early Radiation of Vertebrates. Verlag Dr. Friedrich Pfeil, München, Germany.

HiLton, E. J. 2005. Observations on the skulls of sturgeons (Acipenseridae): Shared similarities of Pseudoscaphirhynchus kaufmanni and juvenile specimens of Acipenser stellatus. Environmental Biology of Fishes, 72:135-144.

HuXLEY, T. H. 1880. On the application of the laws of evolution to the arrangement of the Vertebrata, and more particularly of the Mammalia. Proceedings of the Zoological Society of London, 1880:649-662.

JIN, F. 1995. Late Mesozoic acipenseriforms (Osteichthyes: Actinopterygii) in Central Asia and their biogeographical implications, p. 15-21. In A. Sun and Y. Wang (eds.), Sixth Symposium on Mesozoic Terrestrial Ecosystems and Biota, Short Papers. China Ocean Press, Beijing.

JIN, F. 1999. Middle and Late Mesozoic Acipenseriformes from northern Hebei and western Liaoning, China, p. 188-260. In P.-J. Chen and F. Jin (eds.), Palaeoworld No. 11. Jehol Biota. Press of University of Science and Technology of China, Hefei.

Jin, F., Y. P. Tian, Y. S. YANG, AND S. Y. DENG. 1995. An early fossil sturgeon (Acipenseriformes, Peipiaosteidae) from Fengning of Hebei, China. Vertebrata PalAsiatica, 33:1-16. (In Chinese, with English summary)

John, C. M., K. B. Follmi, E. De Kaenel, T. Adatte, P. Steinmann, AND C. BADERTSCHER. 2002. Carbonaceous and phosphate-rich sediments of the Miocene Monterey Formation at El Capitan State Beach, California, USA. Journal of Sedimentary Research, 72:252-267.

Lagoe, M. B. 1985. Depositional environments in the Monterey Formation, Cuyama Basin, California. Geological Society of America Bulletin, 96:1296-1312.

LAMBE, L. M. 1902. Geological Survey of Canada. 2-New genera and species from the Belly River series (mid-Cretaceous). Contributions to Canadian Palaeontology, 2:23-81.

LAUGiniger, E. M. 1984. An Upper Campanian vertebrate fauna from the Chesapeake and Delaware canal, Delaware. The Mosasaur, 2:141149.

LEIDY, J. 1873a. Notice of fossil vertebrates from the Miocene of Virginia. Proceedings of the Academy of Natural Sciences of Philadelphia, 1873:15.

LeIDY, J. 1873b. Notice of fossil vertebrates from the Miocene of Virginia. American Journal of Science (series 3), 5:311-312.

LEIDY, J. 1873c. Contributions to the extinct Vertebrata of the western territories. Report of the United States Geological Survey of the Territories, number $1,358 \mathrm{p}$.

LinNAEus, C. 1758. Systema Naturae per Regna Tria Naturae, Secundum Claese, Ordines, Genera, Species, cum Characteribus, Differentiis, Synoonymis, Locis. Tomus I (editio decima, reformata). Holminae.

Lofgren, D. L. 1995. The Bug Creek problem and the Cretaceous-Tertiary transition at McGuire Creek, Montana. University of California Publications Geological Sciences, number 140, 185 p.

LU, L. 1994. A new paddlefish from the Upper Jurassic of northeast China. Vertebrata PalAsiatica, 32:134-142.

MacAlpin, A. 1941. Paleopsephurus wilsoni, a new polyodontid fish from the Upper Cretaceous of Montana, with a discussion of allied fishes, living and fossil. Bulletin of the Geological Society of America, 52(Pt. II):1989. (Abstract)

MacAlpin, A. 1947. Paleopsephurus wilsoni, a new polyodontid fish from the Upper Cretaceous of Montana, with a discussion of allied fishes, living and fossil. Contributions from the Museum of Paleontology University of Michigan, 6:167-234.

MAYDEN, R. L., AND B. R. KUHAJDA. 1996. Systematics, taxonomy, and conservation status of the endangered Alabama sturgeon, Scaphirhynchus suttkusi Williams and Clemmer (Actinopterygii, Acipenseridae). Copeia, 1996:241-273.

McLEAN, J. R. 1971. Stratigraphy of the Upper Cretaceous Judith River Formation in the Canadian Great Plains. Saskatchewan Research Council, Geology Division Report, 11, 96 p.

Mitchell, S. L. 1815. The fishes of New York described and arranged. Transactions of the Literary and Philosophical Society of New York, $1: 355-492$.

MÜLLER, J. 1844. Über den bau und die grenzen der Ganoiden und über das natürliche system der fische. Bericht über die zur Bekanntmachung geeigneten Verhandlungen der Akademie der Wissenschaften, Berlin, 1844:117-216.

Nessov, L. A., AND M. N. KaZnyshKin. 1983. New sturgeons from the Cretaceous and Paleogene of the USSR, p. 68-76. In V. V. Menner (ed.), Contemporary Problems of Paleoichthyology. Nauka Press, Moscow. (In Russian)

NiKOlSKII, A. M. 1900. Pseudoscaphirhynchus rossikowi n. gen. et spec. Annuaire du Musée Zoologique de l'Académie Impériale des Sciences des St.-Pétersbourg, 4:257-260. (In Russian)

Osborn, H. F. 1902. Geological Survey of Canada. 1 - Distinctive characters of the mid-Cretaceous fauna. Contributions to Canadian Paleontology, 3:5-21.

PayenberG, T. H. D., D. R. Braman, D. W. Davis, and A. D. Miall. 2002. Litho- and chronostratographic relationships of the SantonianCampanian Milk River Formation in southern Alberta and Eagle Formation in Montana utilising stratigraphy, U-Pb geochronology, and palynology. Canadian Journal of Earth Sciences, 39:1553-1577.

PRIEM, F. 1901. Sur les poissons de l'Éocéne Inférieur des Environs de Riems. Bulletin de la Sociéte Géologique (series 4), 1901:477-504.

PRIEM, F. 1904. Sur les poissoins du Bartonien et les siluridés et acipenséridés de l'Éocéne du Bassin de Paris. Bulletin de la Sociéte Géologique (series) 4, 1904:42-47.

Priem, F. 1908. Etude des Poissons Fossiles du Bassin de Paris. Publications des Annales de Paléontologie, Masson et cie, Paris, $144 \mathrm{p}$.

Purdy, R. W., V. P. Schneider, S. P. Applegate, J. H. McLellan, R. L. Meyer, And B. H. Slaughter. 2001. The Neogene sharks, rays, and bony fishes from Lee Creek Mine, Aurora, North Carolina. Smithsonian Contributions to Paleobiology, 90:71-202.

Rosen, D. E., P. L. Forey, B. G. Gardiner, and C. Patterson. 1981. Lungfishes, tetrapods, paleontology, and plesiomorphy. Bulletin of the American Museum of Natural History, 167:159-276.

Russell, D. A. 1988. A check list of North American marine Cretaceous vertebrates including freshwater fishes. Occasional Papers of the Tyrrell Museum of Palaeontology, 4:1-57.

RUSSELL, L. S. 1964. Cretaceous non-marine faunas of northwestern North America. Royal Ontario Museum Life Sciences Contributions, 61:1-24.

STERnBerG, C. M. 1926. Notes on the Edmonton Formation of Alberta. Canadian Field-Naturalist, 40:102-104.

Swift, C., AND E. Wing. 1968. Fossil bony fishes from Florida. The Plaster Jacket, 7:1-11.

WiLimovsky, N. J. 1956. Protoscaphirhynchus squamosus, a new sturgeon from the Upper Cretaceous of Montana. Journal of Paleontology, 30:1205-1208.

WoODWARD, A. S. 1889a. On the paleontology of sturgeons. Proceedings of the Geological Association, 11:24-44.

Woodward, A. S. 1889b. Catalogue of Fossil Fishes of the British Museum (Natural History), Pt. I. Trustees of the British Museum, London, $474 \mathrm{p}$.

Woodward, A. S. 1895. Catalogue of Fossil Fishes of the British Museum (Natural History), Pt. III. Trustees of the British Museum, London, $544 \mathrm{p}$.

Woodward, A. S., ANd C. D. Sherborn. 1890. A Catalogue of British Fossil Vertebrates. Dulau, London, 396 p.

Yabumoto, Y., Y. Hasegawa, Y. OKaZaKi, A. Koizumi, and T. MuRAMATSU. 1997. Miocene acipenseriform fish remains from the Tomikusa Group in the southern part of Nagano Prefecture, central Japan. Bulletin of the Iida City Museum, 7:117-122.

ZANGERL, R. 1948. The vertebrate fauna of the Selma Formation of Alabama, Pt. I, Introduction. Fieldiana: Geology Memoirs, 3:1-16.

ACCEPTED 13 MAY 2005 